\title{
Responses of European flounder Platichthys flesus populations to contamination in different estuaries along the Atlantic coast of France
}

\author{
Justine Marchand ${ }^{1}$, Arnaud Tanguy ${ }^{2}$, Jean Laroche $^{1, *}{ }^{\text {, Louis Quiniou }}{ }^{1}$, \\ Dario Moraga ${ }^{2}$
}

${ }^{1}$ Laboratoire Ressources Halieutiques - Poissons Marins, and ${ }^{2}$ UMR CNRS 6539, Institut Universitaire Européen de la Mer, Place Nicolas Copernic, 29280 Plouzané, France

\begin{abstract}
Genetic and physiological responses of flounder Platichthys flesus populations to chemical stress were investigated in 3 highly contaminated French estuaries (the Vilaine, Loire and Gironde) and compared to those observed in the Ster estuary, considered as a reference site because of its reletively low level of contamination. In the Vilaine, Loire and Gironde populations, multi-loci heterozygosity (allozymes: PGM, GPI-2, MPI, IDHP, AAT-1, AAT-2) was lower than in the reference site. The mean growth rate was measured by back-calculation from otoliths, and the mean condition factor corresponded to the somatic weight:fish length ${ }^{3}$ ratio. The fish from contaminated estuaries displayed lower values for both parameters than those from the Ster. Among the alleles, PGM 85, AAT-1 95, and to a lesser extent MPI 90, MPI 95 and IDHP 90, could be considered as 'resistant' to contamination. In contaminated estuaries, these alleles were carried by individuals that displayed good fitness, measured as high DNA integrity (low coefficient of variation of DNA content in blood cells) by flow cytometry. The frequencies of these alleles were also more elevated compared to fish from the reference site. Moreover, the comparative analysis of the relationships between genotypic and phenotypic responses of flounder populations to pollution in the 4 studied estuaries highlighted some specificity in relation to contamination typology.
\end{abstract}

KEY WORDS: Flounder · Pollution · Estuaries · Genetic variability · DNA damage

\section{INTRODUCTION}

An emerging topic in ecotoxicology concerns changes observed in the genetic material of pollutant-exposed populations through direct DNA damage, selection, bottleneck or genetic drift (Bickham et al. 2000, Theodorakis 2001). Modifications of allelic or genotypic frequencies in a population submitted to pollution may reduce its adaptability to new environments. Allozyme markers have been successfully used to evaluate the impact of chemical stress, particularly on the genetics of fish populations settled in heavily contaminated rivers (Gillespie \& Guttman 1993, 1999, Benton et al. 1994, Foré et al. 1995). In North America, where the most contaminated rivers display a high proportion of 'resistant' genotypes to pollution, monitoring of particular allelic frequencies for specific allozymes in fish populations could become, in the future, an efficient tool to survey water quality (Heithaus \& Laushman 1997).

Numerous chemicals in the field produce different levels of DNA damage, e.g. DNA strand breakage, chromosomal aberrations, micronuclei formation and variations in nuclear DNA content, which can be assessed by various techniques (Shugart 1999). Because such DNA damage may be associated with some component of fitness, e.g. growth rate, condition factor and fecundity, it can provide information on contaminant-induced effects as well as exposure (Shugart \& Theodorakis 1994, Theodorakis et al. 1997, Steinert et 
al. 1998). In some heavily contaminated rivers, specific genotypes observed in fish populations have been clearly related to particularly low levels of DNA damage, and are thus considered as being 'tolerant' to pollutants (Larno et al. 2001).

The investigations reported here deal with the genetic and physiological responses of European flounder Platichthys flesus populations to contaminants in 3 highly polluted French estuaries (the Vilaine, Loire and Gironde) and a moderately contaminated one (the Ster), hereafter named 'the reference site'. The previous, and first, exploratory survey conducted on a limited number of populations in some of these highly contaminated sites showed a higher occurrence of particular genotypes in fish displaying high DNA integrity (Laroche et al. 2002). The present study was aimed at (1) confirming the general trends previously observed by more extensive analyses on a larger spatio-temporal scale; and (2) exploring the possible relationship(s) between the specific genetic and physiological responses displayed by these contaminated populations, and the chemical typology in the estuaries of concern.

\section{MATERIALS AND METHODS}

Biological model. The European flounder Platichthys flesus is a benthic flatfish commonly distributed in the East Atlantic Ocean. Along the French Atlantic coast, this species lives as a juvenile in estuaries and brackish waters for 2 or $3 \mathrm{yr}$ before it migrates to marine waters to reproduce, from January to March. Post-spawners are generally dispersed in coastal waters from spring to fall. A few individuals recolonise the estuaries in spring, whereas numerous adults stay in marine waters after reproduction (Masson 1987). During the juvenile period in coastal waters, flounders are pervasively exposed to contaminants and have been the subject of numerous studies throughout Europe on the effects of xenobiotics on their organs and populations (Allen et al. 1999, Broeg et al. 1999, Williams et al. 2000, Winzer et al. 2002).

Study sites. Fish were collected in the polyhaline zone of 4 estuaries (Fig. 1). One of them, the Ster basin, is characterised as the 'reference site' in this study because it receives reduced inputs of domestic and agricultural effluents, and no industrial waste. Its low level of contamination has been confirmed by the detection, in mussels, of reduced concentrations in xenobiotics (Table $1 ;$ H. Budzinski pers. comm.). On the other hand, the Vilaine, Loire and Gironde estuaries are heavily anthropogenically impacted and chronically polluted by mixtures of chemicals, variable

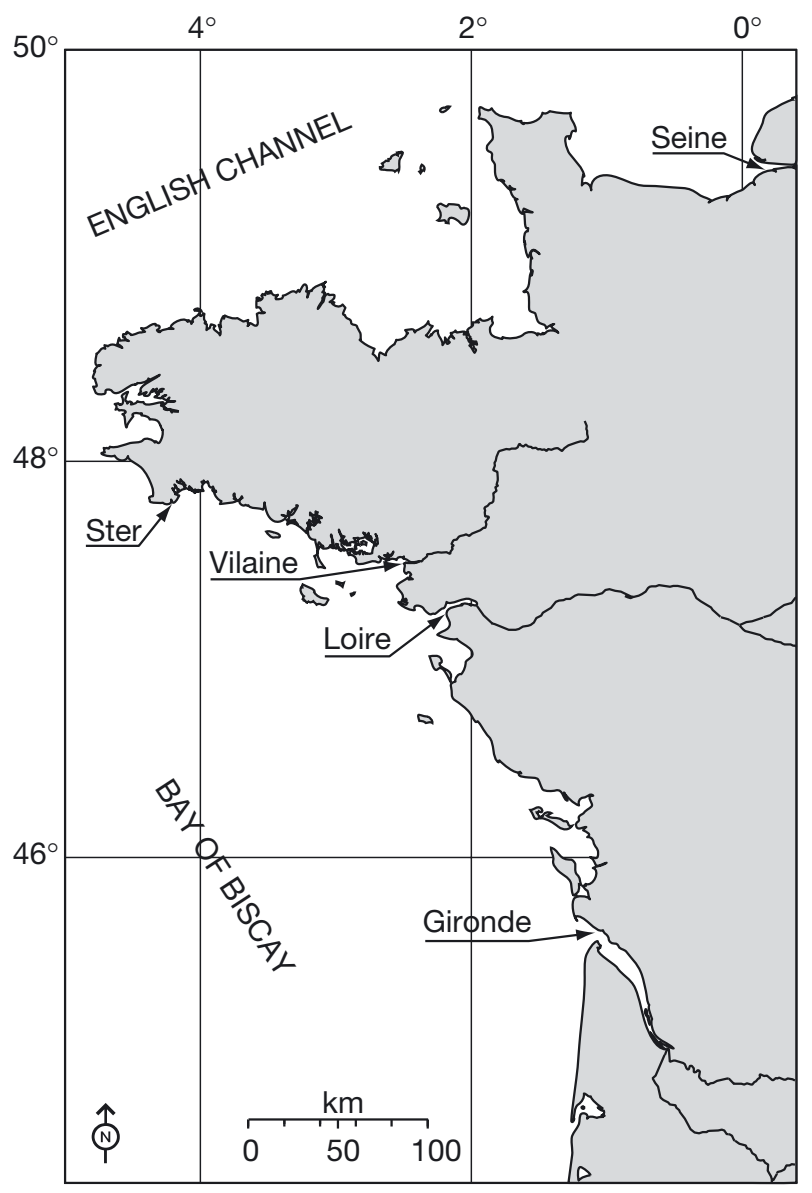

Fig. 1. Sampling sites in 4 highly contaminated estuaries (the Seine, Vilaine, Loire and Gironde) and 1 reference estuary (Ster). (The Seine dataset was published in a previous paper) 
from one estuary to the next (RNO 2001) because of the differing nature and/or proportion of anthropogenic activities. A comparative dataset on heavy-metal and organicpollutant content in mussels and oysters (Table 1) is available only for the Loire and Gironde estuaries (RNO 2001); this table also lists concentrations found in the Seine (see Fig. 1 for location) in order to underline its high level of contamination, which is similar to those reported in heavily polluted estuaries of North America (Munschy et al. 1997). Mussels from the Seine and Loire estuaries contain similar amounts of heavy metals and display a significant level of contamination by cadmium; on the other hand, organic pollutants were 2 or 3 times less concentrated in the Loire than in the Seine. The Gironde estuary is characterised by significant levels of heavy metals (zinc, cadmium and copper) compared to the previous systems, i.e. Loire, Seine, and Ster. No similar data are available for the Vilaine estuary, but water analyses carried out between 1996 and 1999 demonstrated particularly high levels of pesticides (Atrazine, Diuron, Isoproturon) (Forget 1998, SAGE Vilaine 1999) as a result of intensive agriculture, which remains as the major anthropogenic activity in this basin.

Sample strategy and processing. Flounders were caught with gillnets from the Ster and Loire at different times: January and June 2001, January 2002; and April 2001 and May 2002, respectively. The average age of the sample populations was assessed from otolith observation at the $\pm 95 \% \mathrm{CI}$, and their sex ratios (SR) corresponded to the male:female ratio. A total of 79 and 103 fish were captured from the Ster and Loire, respectively, and the population characteristics were: $\mathrm{SR}=0.22$, average age $=3.16 \pm 0.39 \mathrm{yr}$; and $\mathrm{SR}=0.65$, average age $=2.28 \pm 0.13 \mathrm{yr}$, respectively. Trawls were used to collect 30 fish from the Vilaine in April 2002 and a total of 60 fish from the Gironde in November 2001 and March 2002. Their characteristics were: $\mathrm{SR}=0.76$, average age $=2.1 \pm 0.35 \mathrm{yr}$; and $\mathrm{SR}=0.19$, average age $=2.38 \pm 0.39 \mathrm{yr}$, respectively.

The flounders were anesthetized with MS222, and ca. $750 \mu \mathrm{l}$ of blood was collected from the caudal peduncle of each individual using a syringe containing $750 \mu \mathrm{l}$ freezing medium (Vindelov \& Christensen 1990). The blood collected was expelled slowly into a cryo-vial on ice, then placed in dry ice for $30 \mathrm{~min}$, and finally frozen in liquid nitrogen. The total length and somatic weight (total weight less gonad and stomach-content weight) of each fish were measured. Liver and muscle samples were collected and flash-frozen in liquid nitrogen for genetic analyses. All the samples were carried to the laboratory and stored at $-80^{\circ} \mathrm{C}$ until use. Otoliths were extracted from the skull and preserved in alcohol.

Genetic markers. Allozymes were selected after looking at previous studies carried out on the Euro- pean flounder; those chosen had generated reliable results and consistent polymorphism (Berrebi 1988, Borsa et al. 1997, Laroche et al. 2002). Muscle and liver extracts were prepared and zymograms were obtained by migration on starch gels according to Borsa et al. (1997). By using either muscle (m) or liver (1), 6 polymorphic loci were tested, i.e. PGM (m), GPI-2 (m), MPI (1), IDHP (m), AAT-1 (m) and AAT-2 (m) (see nomenclature by Shaklee et al. 1990).

Physiological markers. Analysis of otoliths from European flounders is rather easy, especially when a reflected light is used on the sagitta. This allows detection from a central point, called the nucleus, of successive white and dark zones; the former are large and produced during the spring to autumn period when growth is fast, whereas the latter are reduced and occur over the winter to spring period. Four otolith parameters were measured through image processing (UTHSCA Image Tool v.2): the maximum radius or maximum distance from the nucleus to the periphery $(R)_{i}$ the length at the beginning of the first winter $\left(R_{1}\right)_{i}$ the length at the end of the first winter $\left(R_{2}\right)$; and the length at the beginning of the second winter $\left(R_{3}\right)$.

We used linear regression to estimate the relationship between the total length $\left(L_{t}\right)$ of a fish and $R$ : $L_{\mathrm{t}}=(a R)+b$ (where $a$ and $b$ are constants estimated from measurements of otoliths carried out on 282 individuals). For every fish, $L_{\mathrm{t}}$ was measured at 3 different times: beginning of its first winter $\left(L_{1}\right)_{i}$ end of its first winter $\left(L_{2}\right)$; and start of its second winter $\left(L_{3}\right)$. These different lengths were computed by back-calculation as follows:

$$
L_{i}=\left[\left(a R_{i}+b\right) /(a R+b)\right] \times L_{\mathrm{t}}
$$

The maximal growth rate of flounder is observed during its first 2 yr (Masson 1987), thus, in this study the individual growth rate (GR) was estimated over $1 \mathrm{yr}$ from the difference between $L_{3}$ and $L_{1}$. When fish were too young to measure $L_{3}$, their growth potentials were compared using $L_{2}$. The age of each fish was also assessed by counting the winter zones of the otolith, in order to explore possible relationships between genetic and/or physiological variables and age.

The condition factor is given by the relation $K=$ $\mathrm{Pe} / L^{3}$, where Pe is the somatic weight $(\mathrm{g})$ and $L$ is the total fish length $(\mathrm{mm})$; it was used to investigate possible changes in energy reserves under chemical pressure.

Change in the DNA content was estimated from blood samples by flow cytometry. Mutagenic agents (e.g. PAH, heavy metals, hydrocarbons) cause chromosomal damage, e.g. deletions, breaks, translocations, loss. When unrepaired, these damages can be transmitted to descendant cells, potentially causing variation in the DNA content in the cells of a single individual. Prior to analysis, blood samples were rapidly 
thawed to $4^{\circ} \mathrm{C}$, then stained with propidium iodide for at least $30 \mathrm{~min}$ (Vindelov \& Christensen 1990). To control the variations in flow-cytometry conditions, blood from a single rainbow trout Oncorhynchus mykiss was used as an internal standard and added to each flounder's blood sample. DNA profiles from stained erythrocyte nuclei (20000 nuclei at least) were generated on a Becton Dickinson FACSCalibur flow cytometer. Halfpeak coefficient of variation $(\mathrm{CV})$ of blood-cell DNA content was determined for each profile with WinMDI 2.8 software. The final comparisons were made with $\mathrm{CV}$ data from individuals that displayed normal and symmetrical DNA profiles; samples whose histograms revealed multiple peaks or other asymmetries were discarded. The variability in flow-cytometry conditions was assessed from the profiles characterised by a rainbow trout CV between 2.5 and 2.8. Our assumption was that clastogenic effects of contaminants could result in higher individual CVs, in agreement with previous literature reports about turtles, frogs and fish (Bickham et al. 1988, Easton et al. 1997, Lowcock et al. 1997). Finally, high CVs are likely associated with significant variation in the DNA content of the sample cells, and thus to high chromosomal damage.

Statistical analyses (physiological parameters). A Kolmogorov-Smirnov test was used to determine whether the physiological data ( $K, \mathrm{GR}, \mathrm{DNA}$ damage) were normally distributed in the different study populations. The homogeneity of variances was tested with Bartlett and log ANOVA tests. Once normality and homogeneity of variances was confirmed, ANOVA and Student-Newman-Keuls (SNK) tests were carried out to compare the physiological responses of flounders in the different estuaries.

Genetic analysis. The allelic frequencies at the 6 selected loci, the observed multilocus heterozygosity (Ho), the heterozygosity based on Hardy-Weinberg expected values (He), and allelic diversity (mean number of alleles per locus) were all calculated per population with the GENETIX 3.0 software (Belkhir et al. 1996). Differences in heterozygosity between the polluted and control sites were evaluated with a paired $t$-test using locus as the unit of replication (Leberg 1992). Within each population, deviation from HardyWeinberg equilibrium was determined by computing the inbreeding coefficient (Fis) as follows: Fis = (He - Ho)/He. The significance of Fis was assessed by a Fisher's exact test using the GENEPOP 3.2a software (Raymond \& Rousset 1995).

Allelic frequencies were analysed locus by locus to detect possible heterogeneity between the reference site (the Ster) and the contaminated estuaries (the Vilaine, Loire and Gironde). Chi-square tests were conducted for the PGM locus, whereas GPI-2, MPI, IDHP, AAT-1 and AAT-2 were analysed through
Fisher's exact tests, with some alleles of these last 5 loci being rare. A population differentiation coefficient (Fst) was computed using the GENETIX 3.0 software (Belkhir et al. 1996). Fst significance was assessed by permuted data sets (1000 permutations).

Relationships between genotypes and phenotypes using multifactorial analysis. For each estuary, principal component analysis (PCA) was first conducted on quantitative data, i.e. physiological parameters and individual heterozygosity; the results were expressed on a correlation circle related to the ordination of these variables on the main factorial plan. Secondly, a Hill \& Smith synthetic analysis (Hill \& Smith 1976) was carried out to compute both the genetic and physiological variables, in order to establish the relationship between them on the main factorial plan. The multivariate analyses were all performed with the ADE-4 software (Chessel et al. 1995).

\section{RESULTS}

\section{Genetic variability}

In contaminated systems the observed heterozygosity fell to between 0.121 and 0.144 , and was lower than in the reference site (Table 2). The same trend was

Table 2. Platichthys flesus. Polymorphic loci, alleles and allele frequencies in the flounder populations ( $\mathrm{n}$ : number of fish sampled, Ho: observed heterozygosity, He: expected heterozygosity)

\begin{tabular}{|lrcccc|}
\hline Locus & Allele & Ster & Vilaine & Loire & Gironde \\
\hline PGM & 85 & 0.146 & 0.333 & 0.175 & 0.167 \\
& 100 & 0.842 & 0.667 & 0.825 & 0.833 \\
& 110 & 0.013 & 0.000 & 0.000 & 0.000 \\
GPI-2 & 90 & 0.038 & 0.033 & 0.049 & 0.008 \\
& 100 & 0.962 & 0.950 & 0.947 & 0.992 \\
& 110 & 0.000 & 0.017 & 0.005 & 0.000 \\
MPI & 90 & 0.115 & 0.050 & 0.034 & 0.025 \\
& 95 & 0.103 & 0.000 & 0.019 & 0.025 \\
& 100 & 0.699 & 0.933 & 0.932 & 0.875 \\
IDH & 105 & 0.083 & 0.017 & 0.015 & 0.075 \\
& 90 & 0.038 & 0.050 & 0.044 & 0.042 \\
AAT-1 & 100 & 0.918 & 0.900 & 0.947 & 0.958 \\
& 110 & 0.044 & 0.050 & 0.010 & 0.000 \\
AAT-2 & 95 & 0.006 & 0.033 & 0.024 & 0.025 \\
& 100 & 0.962 & 0.950 & 0.976 & 0.950 \\
& 110 & 0.032 & 0.017 & 0.000 & 0.025 \\
n & 100 & 0.000 & 0.000 & 0.005 & 0.008 \\
Ho & 110 & 0.006 & 1.000 & 0.990 & 0.983 \\
He & & 79 & 30 & 103 & 6.000 \\
& & 0.180 & 0.144 & 0.121 & 0.136 \\
& & 0.182 & 0.161 & 0.115 & 0.127 \\
\hline
\end{tabular}


observed for He obtained at Hardy-Weinberg equilibrium. There was no significant difference in mean observed heterozygosity between the polluted and the reference sites (all $t$-values $\leq 1.21, \mathrm{p} \geq 0.27$, with $5 \mathrm{df}$ ).

For each estuary, $\chi$-square tests showed no temporal variability in allelic frequencies over the study period; therefore, the different samples collected in each estuary were pooled (Table 2). The frequencies of the PGM 85 and AAT-1 95 alleles were more elevated in the heavily contaminated estuaries than in the reference site; for PGM 85, the increase was statistically significant for the Vilaine population $\left(\chi^{2}=9.8\right.$; $\mathrm{p}<0.005$ ), but not significant for the Loire and Gironde sites. On the other hand, none of the increases observed in AAT-1 95 frequency were statistically significant (Fisher's exact tests with $\mathrm{p}>0.05$ ). As for the PGM 100, MPI 90, MPI 95, MPI 105 and AAT-1 110 alleles, a decrease in their respective frequencies was observed in the contaminated estuaries with respect to the Ster (Table 2), but these changes were not statistically significant $\chi^{2}$ tests and Fisher's exact tests with $\mathrm{p}>0.05)$. For the GPI-2 90 allele, the Table 2 data shows a particular trend: from the Ster to the Loire, this allele frequency increased, though not significantly (Fisher's exact test with $\mathrm{p}>0.05$ ).

For each estuary, Fis was computed and found not to be significantly different from zero; this suggests that the reference and contaminated populations were all at Hardy-Weinberg equilibrium. Assessment of the differentiation index, Fst (Table 3), showed significant genetic differentiation between the paired populations of the different estuaries, with the exception of the Gironde-Loire pair $(p>0.05)$. Over the whole data matrix (Table 3), the most significant paired genetic differentiations were found between the Ster and the contaminated estuaries.

\section{Physiological responses}

The linear regressions between $L_{\mathrm{t}}$ (in $\mathrm{mm}$ ) and $R$ (in $\mathrm{mm}$ ) were significantly different (Wilcoxson test, $\mathrm{p}<0.05)$ for the right otolith $\left(L_{\mathrm{t}}=74.358 R+40.962\right.$ with $\mathrm{r}=0.86)$ and the left one $\left(L_{\mathrm{t}}=89.789 R+43.285\right.$ with $\mathrm{r}=0.81$ ). At the confidence level $\mathrm{p}<0.05$, ANOVA and SNK tests on GR allowed a classification of the estuaries as follows: Ster $\left(156.7 \pm 9.3 \mathrm{~mm} \mathrm{yr}^{-1}\right)>$ Vilaine $\left(105.7 \pm 13.8 \mathrm{~mm} \mathrm{yr}^{-1}\right) \approx$ Loire $\left(103.5 \pm 4.6 \mathrm{~mm} \mathrm{yr}^{-1}\right)>$ Gironde $\left(92.6 \pm 6.1 \mathrm{~mm} \mathrm{yr}^{-1}\right)$.
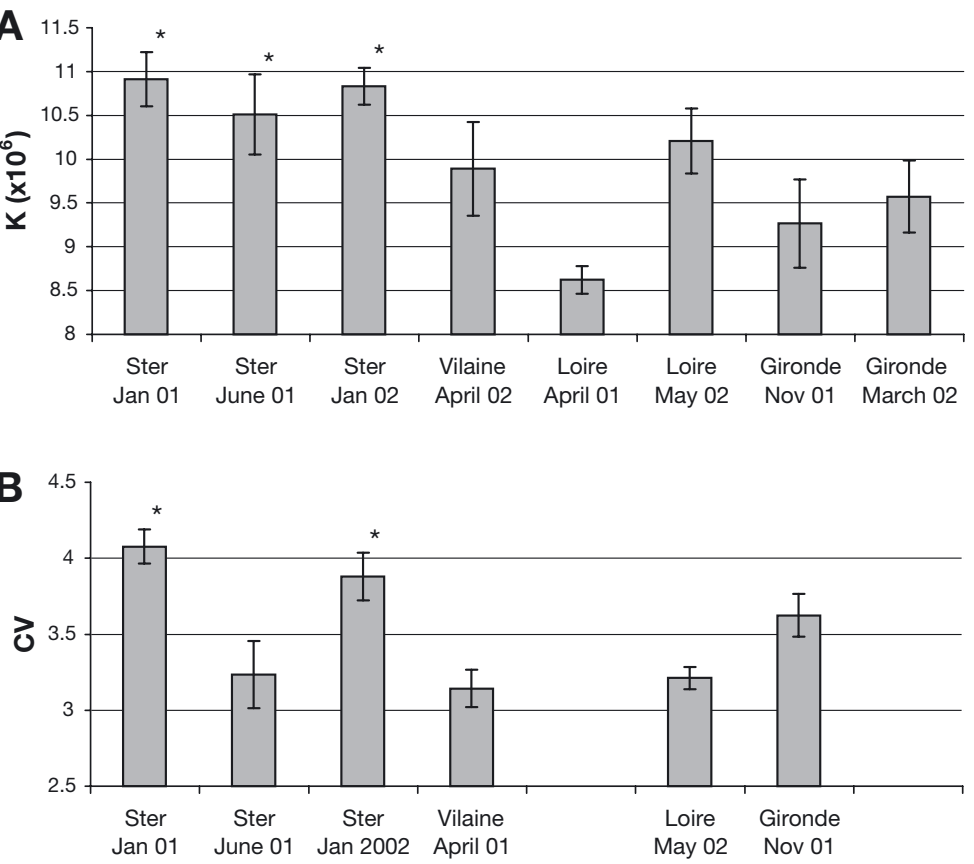

Fig. 2. Platichthys flesus. (A) Condition factor $(K)$ of DNA content and B) coefficient of variation (CV) of DNA content of blood cells, analysed by cytometry, of European flounder from the different estuaries (mean $\pm 95 \%$ CIs). ${ }^{*}$ Significantly different compared to the whole data set (ANOVA and Student-Newman-Keuls [SNK] analysis)

$K$ data were not pooled over the different sampling dates by estuary (Fig. 2) because of their possible relationship with season (Lambert \& Dutil 1997). The ANOVA and SNK analysis showed that the 3 samples from the Ster collected in January and June 2001 and January 2002 displayed a significantly higher $K$ than those found for the fish from the other estuaries $(\mathrm{p}<0.05)$.

The CV-data obtained by flow cytometry on fish blood were also analysed with respect to sampling date and estuary in order to discern possible seasonal variations (Fig. 2). According to ANOVA and SNK analyses the samples collected from the Ster in January 2001 and $2002(\mathrm{p}<0.05)$ exhibited significantly higher CVs than the samples from the other sites, which were not significantly different $(\mathrm{CV} \approx 3.3)$. Moreover, a robust linear regression $\left(\mathrm{R}^{2}=0.91\right)$ be-

Table 3. Platichthys flesus. Genetic differentiation (Fst) computed between the different estuaries $\left({ }^{*} \mathrm{p}<0.05,{ }^{* *} \mathrm{p}<0.01\right.$, $\left.{ }^{* * *} \mathrm{p}<0.001\right)$

\begin{tabular}{|llll|}
\hline & Vilaine & Loire & Gironde \\
\hline Ster & $0.052^{* *}$ & $0.039^{* * *}$ & $0.017^{* *}$ \\
Vilaine & & $0.026^{*}$ & $0.033^{*}$ \\
Loire & & & 0.005 \\
\hline
\end{tabular}




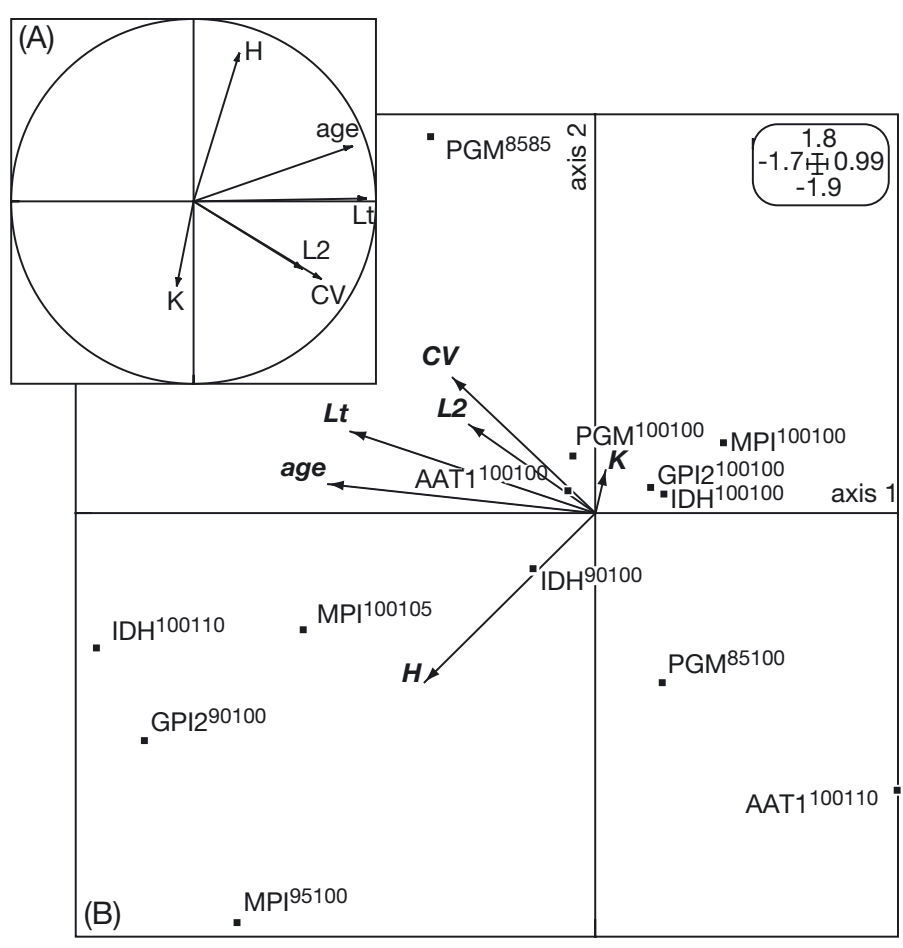

Fig. 3. Platichthys flesus. Principal component analysis (PCA) for European flounder from the Ster estuary. (A) Correlation circle for the ordination of quantitative variables on the main factorial plan. $\mathrm{CV}=$ coefficient of variation of DNA content of blood cells, analyzed by cytometry; $L_{\mathrm{t}}=$ total fish length; $L_{2}=$ estimated length for $1 \mathrm{yr}$ old fish; GR = growth rate; $\mathrm{H}=$ individual heterozygosity; $K=$ condition factor; (B) synthetic analysis linking quantitative variables (vectors) and genotypes (PGM ${ }^{85100}$ : PGM locus, heterozygote with 2 alleles, 85 and 100), on the main factorial plan (ovoid box shows the limit of the plan)

tween CV and age was seen when including all individuals collected from the 4 estuaries.

\section{Relationships between genotypes and phenotypes}

To carry out the factorial analysis for the reference estuary, the samples collected in June 2001 and January 2002 were pooled. Fig. 3A illustrates the PCA (correlation circle) and highlights the relationships between quantitative data. It also shows a positive correlation between CV (half peak coefficient of variation of fish blood) and the estimated length of $1 \mathrm{yr}$ old fish $\left(L_{2}\right)$. One should note that the correlation between CV and total fish length is less marked. The relative orthogonality between the heterozygosity (H-) vector and the $\mathrm{CV}$ - and $L_{2}$ - vectors shows a lack of correlation between these parameters.

The second part of the factorial analysis on the Ster estuary focused on possible relationships between qualitative and quantitative data using the synthetic analysis of Hill \& Smith (Fig. 3B). Forty percent of the total variance was explained by the main factorial plan (Axes 1 and 2). The PGM 85/85 genotype appeared to be related to a relatively high $\mathrm{CV}$, i.e. significant DNA damage, and high growth potential (elevated $L_{2}$ ). On the other hand, heterozygotes for the PGM locus (PGM 85/100) maintained their DNA integrity more efficiently, as shown by their low CVs; moreover, their growth was slow. No particular trend was detected for the most common genotype, PGM 100/100, localised near the origin of the axes. The AAT-1 100/110 genotype was also found to be related to high DNA integrity and moderate growth.

As for the Vilaine estuary, the correlation circle showed a strong negative correlation between $\mathrm{H}$ and $\mathrm{CV}$, i.e. the most heterozygous fish maintained the highest DNA integrity (Fig. 4A). The orthogonality between the CV-H and $K$-vectors indicated no relationship between them. The first 2 axes of the Hill \& Smith analysis (Fig. 4B) explained ca. $36 \%$ of the total variance. The individuals with the PGM 85/100 genotype maintained their DNA integrity better than the homozygous PGM 100/100 situated on the upper left side of the graph (high DNA damage). The MPI 90/100, AAT-1 95/100 and MPI 100/105 genotypes displayed high DNA integrity and GR. GPI-2 90/100 was associated with a high $K$.

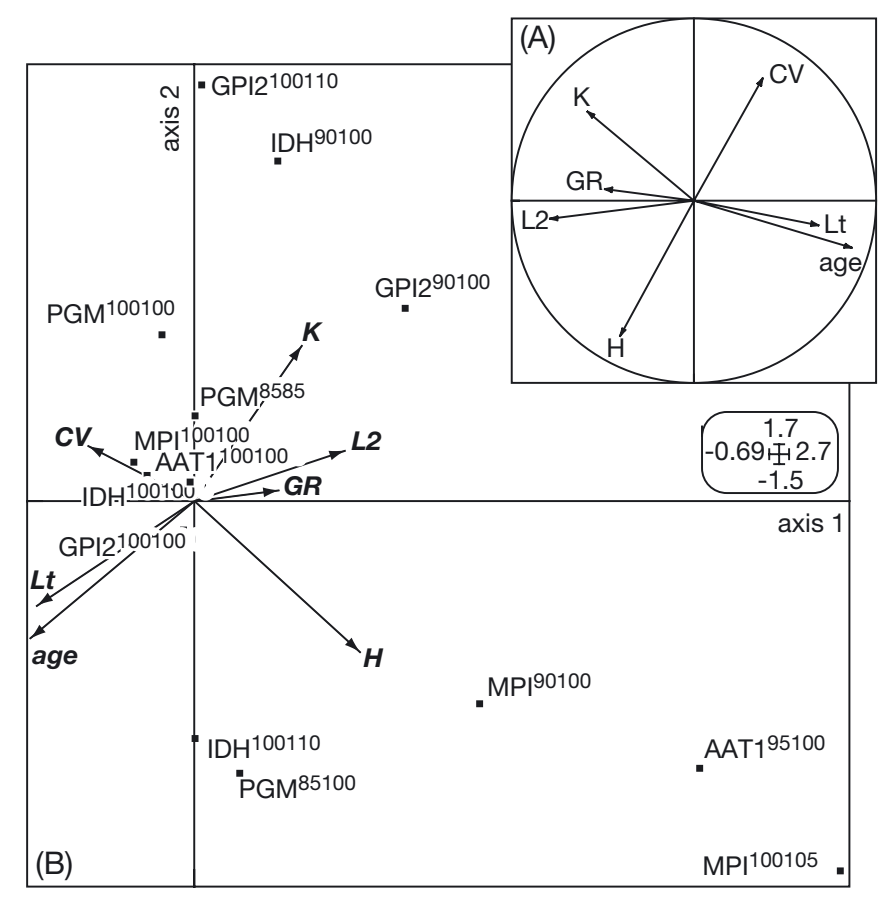

Fig. 4. Platichthys flesus. Principal component analysis (PCA) for European flounder from the Vilaine estuary. See Fig. 3 legend for all other details 
The factorial analysis on the sample collected in May 2002 within the Loire estuary showed a positive, though limited, correlation between CV, $L_{2}$ and GR on the correlation circle (Fig. 5A); moreover, these last

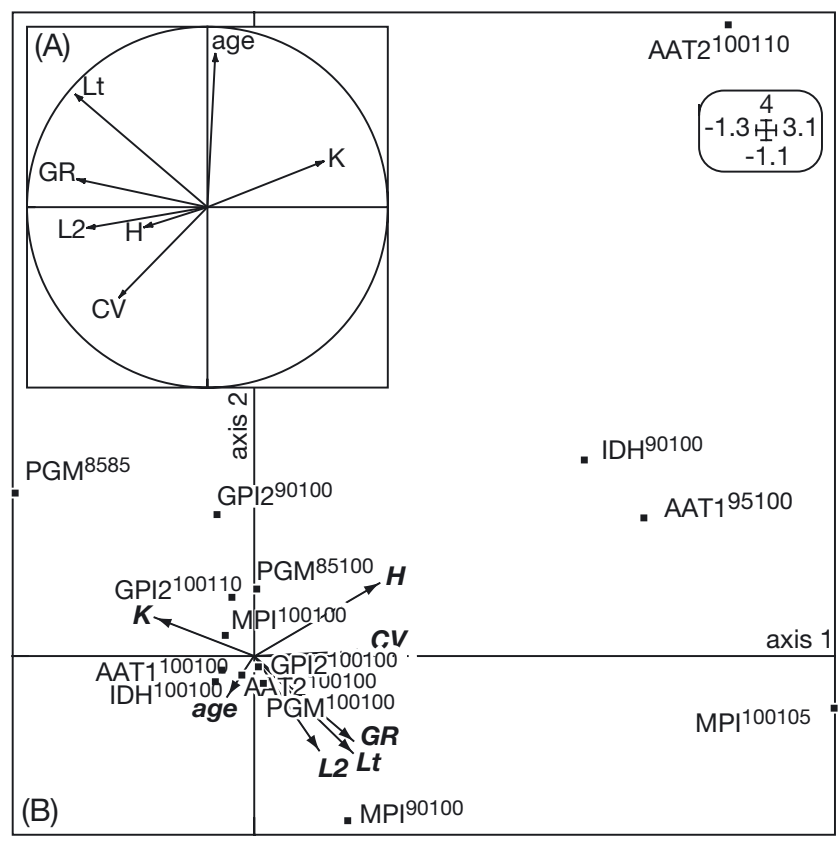

Fig. 5. Platichthys flesus. Principal component analysis for European flounder from the Loire estuary. See Fig. 3 legend for all other details

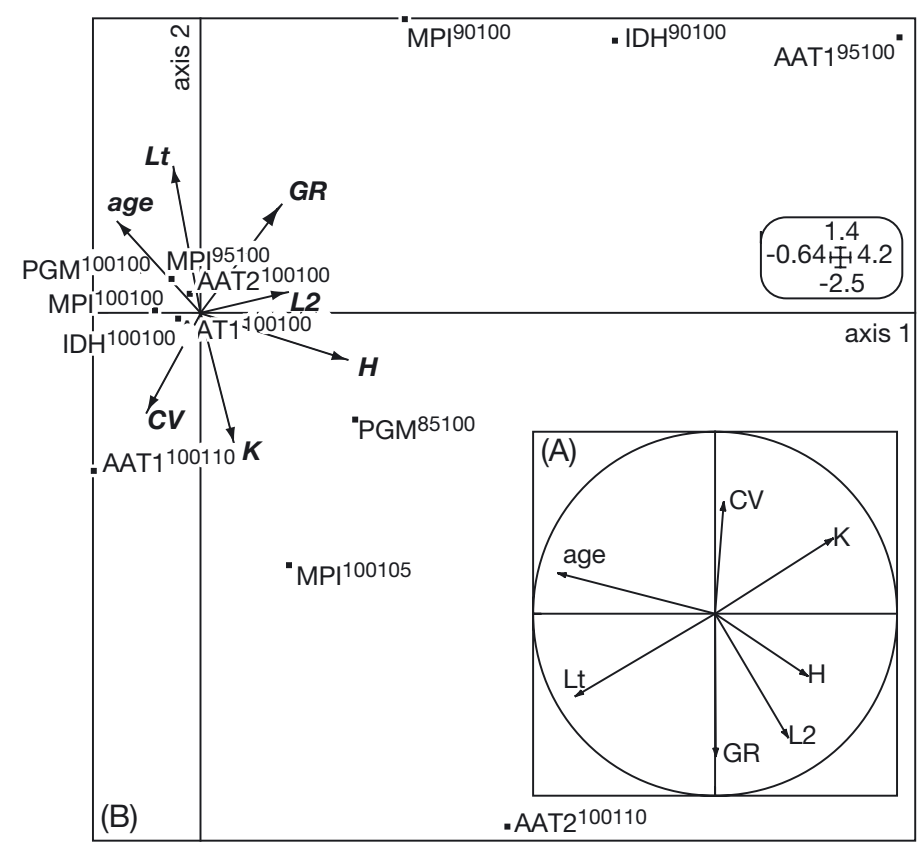

Fig. 6. Platichthys flesus. Principal component analysis for European flounder from the Gironde estuary. See Fig. 3 legend for all other details variables were negatively correlated with $K$. A total of $34 \%$ of the total variance was explained by the first 2 axes of the Hill \& Smith analysis (Fig. 5B). From left to right in the diagram, the first genotype observed is PGM 85/85 (high DNA integrity, low GR, high $K$ ), then PGM 85/100, and finally PGM 100/100 (low DNA integrity and high GR). The MPI 90/100 and MPI 100/105 genotypes showed a reduced ability to maintain their DNA integrity, but showed a high GR and low $K$.

The correlation circle for the Gironde estuary (Fig. 6A) showed a strong negative correlation between $\mathrm{CV}$ and $\mathrm{GR}$, i.e. the individuals that maintained their DNA integrity displayed an elevated GR. Heterozygosity $(\mathrm{H})$ was not related to $\mathrm{CV}$ and appeared to be negatively correlated to fish longevity. Axes 1 and 2 of the Hill \& Smith analysis (Fig. 6B) explained $40 \%$ of the total variance. The MPI 90/100, IDHP 90/100 and AAT-1 95/100 genotypes showed high DNA integrity and GR in contrast to the AAT-1 100/110 genotype.

\section{DISCUSSION}

\section{Genetic responses to chemical stress}

The genetic variability (heterozygosity) observed in the contaminated estuaries, i.e. the Vilaine, Loire and Gironde, was lower (but unsignificantly so) than in the reference site (the Ster). In a previous study on European flounder (Laroche et al. 2002), a similar trend was noticed in the Loire estuary, whereas heterozygosity remained unchanged in the Seine. A decrease in genetic variability may result from genetic bottleneck, drift, historical factors (phylogeography), and/or possible selection of 'tolerant' genotypes (Delpledge 1996, Shugart \& Theodorakis 1998, Bickham et al. 2000, Staton et al. 2001). A genetic bottleneck is unlikely because the flounder sites of reproduction are clearly located outside the estuaries, which thus allows intensive gene flow between neighbouring estuaries or brackish waters (Berrebi 1988). Usually, genetic drift is observed in the field only in very small populations, which makes this assumption unlikely in the large contaminated estuaries where the flounder populations remain relatively numerous, regardless of the river system. It is improbable that such a reduced genetic variability results from historical factors because the flounder populations appear genetically homogeneous over a large area, extending from Portugal to Brittany (Berrebi 1988). Therefore, the most likely hypothesis is a general decrease in genetic variability in response to chemical stress. The only chronically contaminated population known to apparently maintain its genetic diversity is located in the Seine estuary, downstream 
from major cities, which receives a complex mixture of contaminants that can act strongly in heterozygote selection (Larno et al. 2001, Laroche et al. 2002). In the present study, genetic differentiation (Fst for paired populations) was more marked when contaminated populations were compared to the reference one than when comparison was limited to between contaminated populations. This observation suggests that contamination affects genetic diversity. Alterations of genetic diversity due to chemical stress have been reported in several populations in the field (Heithaus \& Laushman 1997, Bickham et al. 2000, Theodorakis 2001, Theodorakis et al. 2001). Since chemical stress in Europe is currently spreading over more extended coastal zones, it may, as a result, lead to significant genetic erosion on impacted flounder populations by decreasing their adaptability to new environmental stress, and increasing the probability of their extinction.

The allelic frequency-distribution highlights convergences among contaminated estuaries. The increase of the PGM 85 frequency between the reference site and the 3 contaminated estuaries ranged between 2 and $18 \%$. Modifications on the PGM locus have already been reported in populations experiencing chemical stress by heavy metals, HAP, PCB, pesticides etc. (Foré et al. 1995, Hebert \& Luiker 1996, Heithaus \& Laushman 1997, Sullivan \& Lydy 1999, Moraga \& Tanguy 2000). Other authors described a 7 to $11 \%$ increase in a pollutant-tolerating allele of PGM in 2 heavily contaminated populations of a freshwater fish compared to a pristine population (Larno et al. 2001), and confirmed this trend over the whole Rhône River basin. Our investigations on flounder populations have led us to believe that contaminants act as selective agents on the PGM locus. Alternatively, one might also consider a relationship between the distribution of PGM alleles and a significant cline with latitude; however, the lack of geographic variation for PGM allozymes makes this assumption unlikely (Oakeshott et al. 1981).

In comparison with the reference flounder population, those from the contaminated estuaries displayed an elevated AAT-1 95 allele frequency and lower frequencies for PGM 100, MPI 90, MPI 95, MPI 105 and AAT-1 110. No particular trend was noticed between pollution and either GPI-2 or IDHP allele distributions.

\section{Physiological responses to chemical stress}

The average GR was significantly higher in the Ster estuary than in the contaminated ones; this observation agrees with that of a previous study (Laroche et al. 2002). Indeed, along the Atlantic French coast, between the Seine in the north and the Gironde in the south, GR was ca. $90 \mathrm{~mm} \mathrm{yr}^{-1}$ and nearly half that observed in the reference estuary (GR Ster $\approx 160 \mathrm{~mm}$ $\mathrm{yr}^{-1}$ ). These data strengthen the hypothesis of a connection between GR and chemical contamination, though it should be considered cautiously as many non-pollution related variables, e.g. ambient temperature, nutrient inputs, water flow and drainage basin area, likely impact fish growth in a specific estuary.

The mean $K$ estimated in the 3 samples from the Ster showed a limited temporal variability and remained higher than those found in contaminated samples; this observation confirms again the low $K$-value previously detected in the anthropogenically impacted Seine estuary (Laroche et al. 2002). The reduced Ks observed in the present study for the polluted estuaries suggest a fish response to chemical contamination through a limited accumulation of energy in muscles. However, their temporal variation in the Loire and Gironde systems is affected not only by pollution, but also by food availability in the environment, growth rate, maturation, and fecundity (Lambert \& Dutil 1997); fish harvesting period affects all these parameters. The fish sampled in the Ster estuary were generally older (mean age $=3.16 \mathrm{yr}$ ) than those from contaminated estuaries (between 2.1 and $2.38 \mathrm{yr}$ ). Different catch efficiencies associated with different fishing gear and/or a higher longevity of the flounder in the reference system may explain the observed difference in age, which could modify the reproductive status of the sample and introduce a bias in the analysis of $K$ between estuaries.

The coefficient of variation of DNA content of blood cells indicated particularly high DNA damage in January (2001 and 2002) in the Ster. An intermittent contamination of this estuary in January 2001 was assumed because of the occurrence of unusual iridescence on the water's surface (Laroche et al. 2002); it was followed by a recovery period, as indicated by the lower average CV in June 2001. As already stated, the older age of fish from the Ster may also explain the high CV since a positive linear relationship was found between $\mathrm{CV}$ and individual age for all the data combined.

The average CVs estimated from fish sampled in the Ster (June), the Vilaine (April), the Loire (May) and the Gironde (November) are not significantly different, but lower than the values found in the reference site in January. This observation suggests that in chronically contaminated estuaries there exists a possible selection of individuals for their ability to repair DNA damage and/or protect their DNA. Thus, it is not necessarily the case that these fish systematically display higher DNA damage compared to individuals from the 'reference site', i.e. those not chronically contaminated (McFarland et al. 1999, Larno et al. 2001). 
These preliminary investigations on the physiological responses of flounder populations to contamination in the field highlight the need for future research into the number of pollution-unrelated variables likely to interfere with responses to chemical stress. They should consider fish-intrinsic factors such as sex, age, nutritional status, reproductive and developmental status, and external factors such as season and water temperature.

\section{Genotype-phenotype coupling}

Table 4 sums up the main trends seen in this study and the previous one (Laroche et al. 2002) regarding the relationship between flounder genotypes and phenotypes in the Loire, Vilaine, Gironde, Ster and Seine estuaries, with respect to the physiological and genetic parameters: $\mathrm{CV}, \mathrm{GR}, K$ and $\mathrm{H}$, and genotypes associated with DNA integrity or damage.

The Seine and Loire estuaries are both subjected to diffuse contamination by a complex mixture of chemicals with, however, PAH and PCB concentrations 2 to 3 times lower in the Loire (RNO 2001). Table 4 shows that in these areas the individuals that are most able to maintain their DNA integrity display the lowest $\mathrm{GR}_{i}$ the same trend is also observed in the Ster estuary. GR is an essential component of individual fitness, but too fast a rate sometimes lowers stress resistance. Fast-growing juveniles tend to be more sensitive than adults to stress-caused damage (Hoffmann \& Parsons 1991). Similar observations were reported in minnow populations under experimental conditions, where contamination counterselected fast-growing fish (Schlueter et al. 1997). The trend reflected by the condition factor associated with the Seine and Loire differs: $K$ is unrelated to $\mathrm{CV}$ in the former and negatively correlated to $\mathrm{CV}$ in the latter (Table 4). Among individuals from the Loire, the ones that efficiently preserve their DNA integrity still store glycogen in their muscles, whereas in the Seine, individuals cannot do this, most likely because of a higher stress level. Above a certain chemical stress threshold, heterozygosity $(\mathrm{H})$ seems to be necessary for survival; this would explain the higher DNA integrity noticed in the heterozygous fish from the Seine estuary; this relationship is not observed in the Loire estuary (Table 4). Similar observations have been reported for radionuclides-exposed sun perch (Shugart \& Theodorakis 1994) and mercury-exposed gambusia (Diamond et al. 1989).

The Vilaine and Gironde estuaries both display specific pollutant typologies. The former is characterised by high pesticide contamination and low metal pollution (Forget 1998). Table 4 shows the lack of correlation between $\mathrm{CV}$ and $\mathrm{GR}$ or $K$, and shows a negative correlation between $\mathrm{CV}$ and $\mathrm{H}$. In this system, het-

Table 4. Platichthys flesus. Trends in chemical contamination, and genetic and physiological responses of flounder populations, in the different estuaries. CV: coefficient of variation of blood-cell DNA content; GR: growth rate; $K$ : condition factor; $\mathrm{H}$ : individual heterozygosity. Fish responses: -, low value; 0, no trend; + , high value. Seine results are from Laroche et al. (2002)

\begin{tabular}{|c|c|c|c|c|c|c|c|}
\hline & $\mathrm{CV}$ & GR & $K$ & $\mathrm{H}$ & $\begin{array}{l}\text { Genotypes associated } \\
\text { with DNA integrity }\end{array}$ & $\mathrm{CV}$ & $\begin{array}{l}\text { Genotypes associated } \\
\text { with DNA damage }\end{array}$ \\
\hline $\begin{array}{l}\text { Seine } \\
\text { Diffuse contamination }{ }^{\mathrm{b}}\end{array}$ & - & - & 0 & + & $\begin{array}{l}\text { PGM 85/85 } \\
\text { MPI 95/100 } \\
\text { IDH 90/100 } \\
\text { AAT-1 95/100 }\end{array}$ & + & $\begin{array}{l}\text { PGM 100/100 } \\
\text { AAT-2 90/100 }\end{array}$ \\
\hline $\begin{array}{l}\text { Loire } \\
\text { Diffuse contamination }{ }^{\mathrm{a}}\end{array}$ & - & - & + & 0 & PGM 85/85 & + & $\begin{array}{l}\text { PGM 100/100 } \\
\text { MPI 90/100 } \\
\text { MPI 100/105 }\end{array}$ \\
\hline $\begin{array}{l}\text { Vilaine } \\
\text { Pesticides }{ }^{\text {b }}\end{array}$ & - & 0 & 0 & + & $\begin{array}{l}\text { PGM 85/100 } \\
\text { MPI 90/100 } \\
\text { MPI 100/105 } \\
\text { AAT-1 95/100 }\end{array}$ & + & PGM 100/100 \\
\hline $\begin{array}{l}\text { Gironde } \\
\text { Heavy metals }^{\mathrm{b}} \\
\text { Diffuse contamination }^{\mathrm{a}}\end{array}$ & - & + & - & 0 & $\begin{array}{l}\text { MPI 90/100 } \\
\text { IDH 90/100 } \\
\text { AAT-1 95/100 }\end{array}$ & + & AAT-1 100/110 \\
\hline $\begin{array}{l}\text { Ster } \\
\text { Weak contamination } \\
{ }^{\mathrm{a}} \text { High level of contamin } \\
{ }^{b} \text { Very high level of cont }\end{array}$ & - & - & 0 & 0 & $\begin{array}{l}\text { PGM 85/100 } \\
\text { AAT-1 100/110 }\end{array}$ & + & PGM 85/85 \\
\hline
\end{tabular}


erozygous individuals are also the most efficient at maintaining their DNA integrity. The Gironde estuary contains a high level of heavy metals. In this particular chemical context, the individuals that efficiently maintain their DNA integrity display high GR and low $K$, in contrast with the previous trends discussed earlier about diffuse contamination in the Loire and Seine.

Over the 5 estuaries considered, differences in energy allocation may explain the various trends observed in the relationships between the different physiological responses, as well as between physiology and heterozygosity. Organism adaptation to contamination implies energetic costs (Forbes 1999); according to the pollutant nature and concentration, the energetic balance would redistribute more or less energy towards particular functions of the organism (reparation/protection of the DNA, growth, energy storage, etc.) in order to ensure better fitness. Table 4 illustrates that the Seine and Loire populations display similar trends, whereas those from the Vilaine and Gironde respond in a different way. Thus, these data corroborate the pollutant typology of the different contaminated estuaries along the French Atlantic coast.

The nature of the genotypes, associated with either DNA integrity or DNA damage, highlights numerous convergences between the different estuaries (Table 4), especially for the PGM, AAT-1, MPI and IDHP loci. The PGM 85 allele, whose frequency is increased in contaminated estuaries, is suspected to be indirectly or directly selected by chemical pressure; this allele is clearly associated with a low CV (at least in the Seine, Loire and Vilaine) and, consequently, with high DNA integrity. This suspected 'pollution tolerant character' to contamination is either linked to a homozygous state, PGM 85/85 (the Seine and Loire), or to a heterozygous state, PGM 85/100 (Vilaine). Moreover, the most common genotype, PGM 100/100, in these 3 contaminated estuaries seems to be 'pollution-sensitive', as displayed by a high $\mathrm{CV}$, whereas in the reference estuary, the PGM 85/85 genotype is clearly counter-selected (highest CV) (Table 4). Therefore, a genotype termed as 'selected' in a highly contaminated system could be considered as 'counterselected' in systems with low-level contamination (Chagnon \& Guttman 1989).

On the other hand, Table 4 shows that, in the Gironde estuary, no differential fitness associated with the PGM 85 allele, and more generally with the PGM locus, is observed. The phosphoglucomutase enzyme (PGM) needs metal cofactors to function (Milstein 1961). This suggests that the very high heavy-metal content of this estuary induces metal competition with PGM cofactors, which partially inhibits enzyme activ- ity and annihilates the potential differences between the activities of allelic variants.

The frequency of the AAT-1 95 allele is higher in the contaminated estuaries (the Seine, Loire, Vilaine and Gironde) than in the reference estuary, whereas the genotype AAT-1 95/100 displays a low CV in these contaminated areas with, however, the exception of the Loire (Table 4). Therefore, the AAT-1 95/100 genotype could also be considered a 'pollution-tolerant' genotype. Conversely, the AAT-1 100/110 genotype is associated with a certain 'sensitivity' to contamination in the Gironde (high CV), whereas in the reference site it is associated with a high DNA integrity (low CV) (Table 4). AAT-1 110 illustrates again the possible 'selection'/'counter-selection' with respect to contamination level within the estuary; this hypothesis is reinforced by the lower frequency (or even disappearance) of this allele in the Seine, Loire and Gironde.

In this study, the increase in the PGM 85 and AAT-1 95 allele-frequencies in contaminated estuaries vs the reference system is rather limited, ca. 2 to $3 \%$. The high gene flow from breeding areas into the contaminated estuaries likely homogenises genetic diversity, and partially masks the selective chemical-related pressure. More generally, gene flow from neighbouring populations may slow down the speed at which the population adapts to pollutants, and thus prevents further detection of 'resistant' alleles at the population level (Taylor \& Georghiou 1979, Roush \& McKenzie 1987). The exceptional increase of $18 \%$ for the PGM 85 allele in the Vilaine population could result from selection induced by a simpler mixture of contaminants compared to other estuaries; contaminant complexity likely lowers selection intensity for the individual toxicants (Klerks 1999).

In conclusion, the present study, on a more extensive dataset than previous studies, confirms the validity of the genetic and physiological markers used in our previous survey of polluted flounder populations (Laroche et al. 2002). For contaminated populations considered individually, (1) particular alleles and genotypes are likely indirectly or directly selected by chemical stress and display higher DNA integrity over the whole population; and (2) the relationships between genotypes and phenotypes highlight specific elements of the population response in relation to pollutant estuarine typology.

Acknowledgements. The authors are grateful to the fishermen L. Vilaine, R. Triballier and J. Gouyen and also to the staff of the 'Unité Ressources Aquatiques Continentales' (CEMAGREF, Cestas; trawler 'Esturial') for sampling and field assistance, and to H. Budzinski (LPTC Bordeaux) for analysing the chemical contamination in mussels of the reference site. Many thanks to S. Rousseau for her help regarding technical problems and to Brenda J. Landau for revising the English. 


\section{LITERATURE CITED}

Allen Y, Scott AP, Matthiesen P, Haworth S, Thain JE, Feist S (1999) Survey of estrogenic activity in United Kingdom estuarine and coastal waters and its effects on gonadal development of the flounder Platichthys flesus. Environ Toxicol Chem 18(8):1791-1800

Belkhir K, Borsa P, Goudet P, Bonhomme F (1996) GENETIX, logiciel sous Windows pour la génétique des populations. Laboratoire Génome et Populations, CNRS UPR 9060, Université de Montpellier II (also available at www.univmontp2.fr/genome-pop/genetix.htm)

Benton MJ, Diamond SA, Guttman SI (1994) A genetic and morphometric comparison of Helisoma trivolvis and Gambusia holbrooki from clean and contamined habitats. Ecotoxicol Environ Safety 29:20-37

Berrebi P (1988) Génétique des populations marines: le modèle "flet » (Platychthys flesus L.1758, Téléostéen, Pleuronectidé). Thèse d'état, Université des Sciences et Techniques du Languedoc, Montpellier

Bickham JW, Hanks BG, Smolen MJ, Lamb T, Gibbons JW (1988) Flow cytometric analysis of the effects of low-level radiation exposure on natural populations of slider turtles (Pseudemys scripta). Arch Environ Contam Toxicol 17: 837-841

Bickham JW, Sandhu S, Hebert PDN, Chikhi L, Athwal R (2000) Effects of chemical contaminants on genetic diversity in natural populations: implications for biomonitoring and ecotoxicology. Mutation Res 463:33-51

Borsa P, Blanquer A, Berrebi P (1997) Genetic structure of the flounders Platichthys flesus and P. stellatus at different geographic scales. Mar Biol 129:233-246

Broeg K, Zander S, Diamant A, Korting W, Kruner G, Paperna I, Westernhagen HV (1999) The use of fish metabolic, pathological and parasitological indices in pollution monitoring. Helgol Mar Res 53:171-194

Changnon NL, Guttman, SI. (1989) Differential survivorship of allozyme genotypes in mosquitofish populations exposed to copper or cadmium. Environ Toxicol Chem 8: 319-326

Chessel D, Dolédec S, Thioulouse J (1995) ADE Version 4: HyperCard Stacks and Programme. Library for the Analysis of Environmental Data. URA CNRS 1451, Université Lyon 1 (also available at http://biomserv.univ-lyon1.fr/ade4.html)

Depledge MH (1996) Genetic ecotoxicology: an overview. J Exp Mar Biol Ecol 200:57-66

Diamond SA, Newman MC, Mulvey M, Dixon PM, Martinson D (1989) Allozyme genotype and time to death of mosquitofish, Gambusia affinis (Baird and Girard), during acute exposure to inorganic mercury. Environ Toxicol Chem 8:613-622

Easton MDL, Kruzynski GM, Solar II, Dye HM (1997) Genetic toxicity of pulp mill effluent on juvenile chinook salmon (Onchorhynchus tshawytscha) using flow cytometry. Wat Sci Technol 35 (2-3):347-355

Forbes VE (1999) Current topics in ecotoxicology and environmental chemistry: genetics and ecotoxicology. Taylor \& Francis, London

Foré SA, Guttman SI, Bailer AJ, Altfater DJ, Counts BV (1995) Exploratory analysis of population genetic assessment as a water quality indicator. I. Pinephales notatus. Ecotoxicol Environ Safety 30:24-35

Forget J (1998) Impact neurotoxique de contaminants (pesticides et métaux) sur un crustacé marin Tigriopus brevicornis (Müller) caractérisation de la cholinestérase et application à la surveillance des effets des polluants sur l'environnement marin. PhD thesis, Université Paris VI
Gillepsie RB, Guttman SI (1993) Correlation between water quality and frequencies of allozyme genotypes in spotfin shiner (Notropis spilopteris) populations. Environ Pollut 81:147-150

Gillepsie RB, Guttman SI (1999) Chemical-induced changes in the genetic structure of populations: effects on allozymes. In: Forbes VE (ed) Genetics and ecotoxicology. Taylor \& Francis, London, p 55-77

Hebert PDN, Luiker M (1996) Genetic effects of contaminant exposure-towards an assessment of impacts on animal populations. Sci Total Environ 191:23-58

Heithaus MR, Laushman RH (1997) Genetic variation and conservation of stream fishes: influence of ecology, life history, and water quality. Can J Fish Aquat Sci 54:1822-1836

Hill MO, Smith AJE (1976) Principal component analysis of taxonomic data with multi-state discrete characters. Taxon 25:249-255

Hoffmann AA, Parsons PA (1991) Evolutionary genetics and environmental stress. Oxford Science Publications, Oxford

Klerks PL (1999) The influence of contamination complexity on adaptation to environmental contaminants. In: Forbes VE (ed) Genetics and ecotoxicology. Taylor \& Francis, London, p 103-121

Lambert Y, Dutil JD (1997) Can simple condition indices be used to monitor and quantify seasonal changes in the energy reserves of Atlantic cod (Gadus morhua)? Can J Fish Aquat Sci 54(Suppl 1):104-112

Larno V, Laroche J, Launey S, Flammarion P, Devaux A (2001) Responses of chub (Leuciscus cephalus) populations to chemical stress, assessed by genetic markers, DNA damage and cytochrome P450 1A induction. Ecotoxicology 10: $145-158$

Laroche J, Quiniou L, Juhel G, Auffret M, Moraga D (2002) Genetic and physiologic responses of flounder (Platychthys flesus) populations to chemical contamination in estuaries. Environ Toxicol Chem 21(12):2705-2712

Leberg PL (1992) Effects of population bottlenecks on genetic diversity as measured by allozyme electrophoresis. Evolution 46(2):477-494

Lowcock LA, Sharbel TF, Bonin J, Ouellet M, Rodrigue J, DesGranges JL (1997) Flow cytometric assay for in vivo genotoxic effects of pesticides in green frogs (Rana clamitans). Aquat Toxicol 38:241-255

Masson G (1987) Biologie et écologie d'un poisson plat amphihalin, le Flet (Platychthys flesus flesus, Linné, 1758) dans l'environnement ligérien: distribution, démographie, place au sein des réseaux trophiques. $\mathrm{PhD}$ thesis, Université de Bretagne Occidentale, Brest

McFarland VA, Inouye LS, Lutz CH, Jarvis AS, Clarke JU, Mc Cant DD (1999) Biomarkers of oxidative stress and genotoxicity in livers of field-collected brown bullhead, Ameiurus nebulosus. Arch Environ Contam Toxicol 37: 236-241

Milstein C (1961) The mechanism of activation of phosphoglucomutase by chelating agents. Biochem J 79:584-590

Moraga D, Tanguy A (2000) Genetic indicators of herbicide stress in the pacific oyster Crassostrea gigas under experimental conditions. Environ Toxicol Chem 19: 706-711

Munschy C, Mosan K, Truquet I, Tronczynski J (1997) Caractérisation chimique de la contamination organique dans l'estuaire de la Seine. Rapport Seine-Aval 1996 /FIN-3, Agence de l'eau Seine-Normandie, Nanterre

Oakeshott JG, Chambers GK, Gibson JB, Willcocks DA (1981) Latitudinal relationships of esterase- 6 and phosphoglucomutase gene frequencies in Drosophila melanosgaster. Heredity 47:385-396 
Raymond M, Rousset F (1995) GENEPOP (Version 1.2): population genetics software for exact tests and ecumenicism. J Hered 86:248-249

RNO (Réseau National d'Observation) (2001) Qualité du milieu marin littoral. IFREMER, Nantes (also available at: www.ifremer.fr/delao/surveillance/reseau/rno/mv.html)

Roush RT, Mc Kenzie JA (1987) Ecological genetics of insecticide and acaricide resistance. Annu Rev Entomol 32: 361-380

SAGE (Schéma d'aménagement et de gestion des eaux) Vilaine (1999) Projet de schéma d'aménagement et de gestion des eaux de la Vilaine, Atlas. Institution d'Aménagement de la Vilaine, La Roche Bernard

Schlueter MA, Guttman SI, Oris JT, Bailer AJ (1997) Differential survival of fathead minnows, Pimephales promelas, as affected by copper exposure, prior population stress, and allozyme genotypes. Environ Toxicol Chem 16:939-947

Shaklee JB, Allendorf FW, Morizot DC, Whitt GS (1990) Gene nomenclature for protein-coding loci in fish. Trans Am Fish Soc 119:2-15

Shugart L, Theodorakis C (1994) Environmental genotoxicity: probing the underlying mechanisms. Environ Health Perspect 102:13-17

Shugart L, Theodorakis C (1998) New trends in biological monitoring: application of biomarkers to genetic ecotoxicology. Biotherapy 11:119-127

Shugart LR (1999) Structural damage to DNA in response to toxicant exposure. In: Forbes VE (ed) Genetics and ecotoxicology. Taylor \& Francis, London, p 151-167

Staton JL, Schizas NV, Chandler GT, Coull BC, Quattro JM (2001) Ecotoxicology and population genetics: the emergence of 'phylogeographic and evolutionnary ecotoxicology'. Ecotoxicology 10:217-222

Steinert SA, Streib-Montee R, Leather JM, Chadwick DB

Editorial responsibility: Otto Kinne (Editor),

Oldendorf/Luhe, Germany
(1998) DNA damage in mussels at sites in San Diego Bay. Mutation Res 399:65-85

Sullivan KB, Lydy MJ (1999) Differences in survival functions of mosquitofish (Gambusia affinis) and sand shiner (Notropis ludibundus) genotypes exposed to pesticides. Environ Toxicol Chem 18:906-911

Taylor CE, Georghiou GP (1979) Suppression of insecticide resistance by alteration of gene dominance and migration. J Econ Entomol 72:105-109

Theodorakis CW (2001) Integration of genotoxic and population genetic endpoints in biomonitoring and risk assessment. Ecotoxicology 10:245-256

Theodorakis CW, Blaylock BG, Shugart LR (1997) Genetic ecotoxicology I. DNA integrity and reproduction in mosquitofish exposed in situ to radionuclides. Ecotoxicology 6:205-218

Theodorakis CW, Bickham JW, Lamb T, Medica PA, Barrett Lyne $T$ (2001) Integration of genotoxicity and population genetic analyses in kangaroo rats (Dipodomys Merriam) exposed to radionuclide contamination at the Nevada test site, USA. Environ Toxicol Chem 20:317-326

Vindelov LL, Christensen IJ (1990) A review of techniques and results obtained in one laboratory by an integrated system of methods designed for routine clinical flow cytometric DNA analysis. Cytometry 11:753-770

Williams TD, Lee JS, Sheader DL, Chipman JK (2000) The cytochrome P450 1A gene (CYP1A) from European flounder (Platichthys flesus), analysis of regulatory regions and development of a dual luciferase reporter gene system. Mar Environ Res 50:1-6

Winzer K, Van Noorden CJF, Kohler A (2002) Glucose-6phosphate dehydrogenase: the key to sex-related xenobiotic toxicity in hepatocytes of European flounder (Platichthys flesus)? Aquat Toxicol 56:275-288

Submitted: November 13, 2002; Accepted: July 8, 2003

Proofs received from author(s): September 8, 2003 